\title{
HISTOMORPHOLOGY, HISTOMETRIC AND HISTOCHEMICAL STRUCTURE OF PARTRIDGE (ALECTORIS CHUKAR) OF PECTEN OCULIIN DIFFERENT GENDER
}

\author{
Hatice YAREN KULOĞLU ${ }^{1 *}$ and Murat BOYDAK ${ }^{2}$ \\ $1 *$ Department of Histology and Embryology, Faculty of Veterinary Medicine, University of Aksaray, Aksaray, \\ Turkey \\ ${ }^{2}$ Department of Histology and Embryology, Faculty of Veterinary Medicine, University of Selcuk, Konya, Turkey
}

http://doi.org/10.35410/IJAEB.2019.4403

\begin{abstract}
The pecten oculi is a highly vascular and pigmented structure peculiar to the avian eye. Birds have thicker retinas compared to mammals but do not have retinal blood vessels. Therefore, it has been suggested that the main function of pecten oculi is to supply nutrition for the a vascular avian retina. The aim of this study was to determine the presence of a difference between the pecten oculi of male and female individuals as well as the histomorphological, histometric and histochemical methods of Partridge of pecten oculi.
\end{abstract}

Materials and Methods: In this study, 12 healthy adults ( 6 male, 6 female) were used. The pecten oculi tissues were extirpated and fixed in $10 \%$ formaldehyde for $24 \mathrm{~h}$. and were embedded in paraffin. The histological and histochemical staining techniques were employed on $5 \mu \mathrm{m}$ sections.

Results: The partridges (Alectoris chukar) had a pleated-type which displayed folded structure. The numbers of pleats of pecten oculi were 13-14 in partridge. Light microscopic investigation demonstrated that pecten oculi is basically composed of numerous capillaries, large blood vessels, and pigment cells. The capillaries are surrounded by thick basal membrane. Blood vessels were larger in diameter (Female:13,17 $\mu \mathrm{m}$; male:13,18 $\mu \mathrm{m}$ ), fewer in numbers, and the capillary vessels were smaller in diameter (Female:2,38 $\mu \mathrm{m}$; male:2,40 $\mu \mathrm{m}$ ) and more in numbers. In addition, pigmented cells were observed around the capillaries. In the PAS staining method, PAS positive reaction was observed around blood vessels, capillaries and pigment cells. However, reticular fibers were not found in the Gordon Sweet stain.

Conclusion: In our study, there was no difference between male and female pecten oculi.

Keywords: Pecten oculi, Avian, Partridge, Alectoris chukar

\section{INTRODUCTION}

In all vertebrates, the outer retina which includes the retinal epithelium (RPE) and photoreceptors (rods and cones) is supplied by the large fenestrated capillaries of the choriocapillaris. In most vertebrates a second vascular system nourishes the inner retina which includes all layers vitreadto the photoreceptors. This other vascular supply which is termed a supplemental nutritive 
device (SND) (Walls1942) or supplementary retinal circulation (Rodieck 1973)can take several forms, but in avian species it is representedas the pecten oculi.

The pecten oculi in the avian is an interesting structure that defies functional analyses, despite the fact that it has been studied for over 300 years (Brach 1977). In avian, pecten oculi has a very vascular and pigmented structure (Kiama et al 1994,Gultiken et al 2012). It is located at the head of the optic nerve and extends from the retina towards the vitreous part (Braekevelt 1988, Orhan et al 2011). The size of the pecten oculi depends on the visual needs of the bird. Thus while birds active in the daytime have a large and highly complex pecten oculi with many folds; birds active at night have a relatively small and simple pecten oculi (Meyer 1977).

Histological features of the pecten oculi in all birds are very similar. It is composed of a thinly pleated plexus consisting of very large capillary vessels assembled by a sparse matrix of pigmented stromal cells. In most birds, the pecten apex is held together by a densely pigmented, fibrous 'bridge' of tissue which has a reduced vascularization with respect to the pecten pleats. The pecten oculi is attached basally to the optic nerve head and distally to the vitreous body by fine strands of vitreous tissue which interdigitates with processes of the bridge cells (Brach 1977). In the avian, retina is thicker than mammals and retinal blood vessels are absent (Pettigrew 1990). Therefore, it is suggested that the avascular retina of the pecten oculi basic function is feeding(Kiama et al 1994). One of the functions of the pecten oculi is the formation of the blood retinal barrier (Wolburg 1999). The endothelia of the pectineal capillaries are continuous, possessing elaborate tight junctions. Also two barrier-specific proteins, that is, the HT7-antigen and the glucose transporter isoform GluT-1, are expressed by the endothelial cells (Gerhardt 1996). We did not come across any works on Partridge (Alectoris chukar) pecten oculi in the literature after the review we made. For this reason, we believe that the data obtained with this study will contribute to the literature in a good way.

\section{MATERIALS AND METHOD}

In this study, 12 healthy adult ( 6 male, 6 female) partridge purchased from a commercial farm (Turkey / Antalya) were used. Before the study started, it was approved by Selcuk University Veterinary Faculty Ethical Committee (SÜVFEK) with decision dated 25.03.2014 and numbered 2014/11. The animals were kept in natural light, humidity and temperature conditions and allowed to freely use water and food.

Thepecten oculi of 12 healthy adults (6 male, 6 female) Partridge (Alectoris chukar) was investigated. The animals were sacrificed and the eye rapidly removed. The eyeballs were cut at the equator, and the posterior half which contained the pecten oculi was photographed using digital camera attached stereomicroscope (Nikon SMZ- 2T, Nikon Corp., Tokyo,Japan). The number of Alectoris chukarpecten oculi was counted in stereomicroscope images. Each pecten was carefully dissected out and cut into smaller pieces for light microscopy processing. Then they were fixed in $10 \%$ buffered formalin for histologic examination. After the fixation, the samples dehydrated in increasing concentrations of ethanol,cleared with xylene, and embedded in paraffin. The serial sections from the apex to the base of pecten were cutin $5 \mu \mathrm{m}$ thick, and the sections were stained using Mallory triple technique (Culling 1985), periodic-acid Schiff (PAS) 
reaction for basement membrane composed of glycoconjugates (Cook 1990) and Gordon sweet (GS) staining for the presentation of the reticular fibres method (Lillie 1965).

All examples were examined under light microscope (Leica DM-2500 model with DFC-320 camera attachment giving digital images). The diameter of the capillaries and thickness of capillary basement membrane of pecten oculi were measured with IM-50 image analysis program.

\section{RESULT}

The pecten of the Partridge (Alectoris chukar), is situated over the optic nerve head and projects out into the vitreous chamber. Because of the pigmentation pecten oculiwas observed in dark brown to black (Figure 1).

The pecten oculi consists of the several thin folds which confluence each other at the apex were very delicate (Figure2). In series transverse sections it was revealed that each fold has a large blood vessel surrounded by many capillaries having high endothelium and thick basement membrane. In addition, pigmented cells were observed in the around capillaries and blood vessels (Figure 3a, 3b; $a=$ female, $b=$ male). In the PAS staining method, PAS positive reaction was observed around blood vessels, capillaries and pigment cells (Figure 4a, 4b; a =female, $b=$ male). However, reticular fibers were not found in the Gordon Sweet stain. The number of pleats and the other morphometric parameters of pecten oculi were illustrated in Table1.

\section{DISCUSSION}

The pecten oculi is found in the vitreous chamber of the eye of all avians (Rochon- Duvigneaud 1943) and it is considered an indirect retinal trophic system (Michaelson1954, Puzzolo 1994), more effectively functioning during saccadic oscillations (Pettigrew et al 1990). It is composed of three different parts: the base, optic nerve head andthe folds.In this study, pecten oculi of chukar Partridge is composed of three different parts.

The base plays a relevant mechanic role, as it providesstrong insertion of the pecten on the adjacent ocular layers along a zigzag line (Puzzolo et al 1985). This arrangement seems to be more functional than a rectilinear one in increasing its mechanical stability and its ability to withstand the inertial forces of the adjacent vitreous body (Tucker 1975). Furthermore, it represents the site where the larger vessels (arterioles and venules) are found (Hossler and Olson 1984). In the budgerigar these vessels are placed along the basal part, close to the optic nerve fibers (Kiama et al 1994, Braekevelt 1998, Rahman et al 2010), is composed only by capillaries. In this study, chukar partridge of pecten oculi was observed to have blood vessels of different sizes.

As to the folds, a relationship was proposed between the number of the pleats and the circadian activity and/ or the visual requirements of the single species (Braekevelt, 1998). In fact, a large and complicated pecten with $15-20$ pleats is generally observed in photically active and visually oriented avians, whereas a pecten provided of smaller size and 4-5 pleats is found in avians with crepuscular or nocturnal habits and with reduced visual acuity. 
The location of the pecten oculi in Alectoris chukar used in this study conformed to that reported in other bird species. We observed that Alectoris chukar had a pleated-type pecten oculi which displayed folded structure.

In this study, we found the number of Partridge pecten oculi pleats as 13-14. Previous researches showed that in other diurnal species such as in malard pecten oculihas 12-14 (Braekevelt 1990), great blue heron has 14-15 (Braekevelt 1991), emu has 3-4 (Braekevelt 1993), American crow has 22-25 (Braekevelt 1994), Australian galah has 20-25 (Braekevelt 1996),black kite has 12-13 (Kiama et al 1994, Kiama et al 2001), domestic poultry has 16-18 (Kiama et al 2001), jungle crow has 24-25 (Rahman et al 2010), quail has 19 (Orhan et al 2011), common buzzard has 1718 (Gultiken et al 2012), budgerigar has 10-12 (Micali et al 2012),duck has 12, pigeon has 13-14, turkey has 21-22, starling has 17 (Dayan and Ozaydin 2013), stork has 15-17 (Onuk et al 2013) folds. However, nocturnal birds have small pectens such as nighthawk that has 4-5 (Braekevelt 1984),barred owl that has 8-10 (Smith et al 1996) and spotted eagle owl that has 5-6 (Kiama et al 2001) folds.

Although the functional morphology of pecten oculi is related to the life style of the avian (Kiama et al 2001), findings from this study and previous studies (Kiama et al 2006) show that pecten oculi mainly consists of numerous capillaries, large blood vessels and pigment cells in various avian species. The capillaries are surrounded by thick basal membrane in pecten oculi of all investigated species in this study as described in pervious study (Braekevelt 1988, Braekevelt 1990,Braekevelt 1994, Braekevelt 1996,Dayan and Ozaydın 2013). It has been suggested that the thickened basal layer may support fragile endothelial cells with very thin cell bodies and numerous microfolds (Braekevelt 1988,Braekevelt 1996).

In this study, pigment cells were observed around the capillaries. The close relationship between pigment cells and capillary vessels has been reportedin the black kite (Kiama et al 2001), ostrich (Kiama et al 2006), and jungle crow (Rahman et al 2010), quail (Orhan et al 2011), storks (Onuk et al 2013), duck, pigeon, turkey, and starling (Dayan and Ozaydin 2013). It has suggested that pigmented cells provide the structural reinforcement to pecten oculi for keeping it firmly erectile within the gel-like vitreous and also protect the blood vessels against damage from ultraviolet light (Braekevelt 1988, Kiama et al 1994,Braekevelt 1996).

In this study, it was determined whether there is a difference between male and female individuals, as well as histomorphological, histometric and histochemical properties of Partridge (Alectoris chukar) pecten oculi. The partridges (Alectoris chukar) had a pleated-type which displayed folded structure. The numbers of pleats of pectens were 13-14 in partridge. Light microscopic investigation demonstrated that pecten oculi is basically composed of numerous capillaries, large blood vessels, and pigment cells. The capillaries are surrounded by thick basal membrane. Onuk et al (2013) reported that the blood vessels of the storks were 40-45 $\mu \mathrm{m}$ in diameter and the capillary vessels were $2-5 \mu \mathrm{m}$ in diameter.Dayan and Ozaydin (2013) reporded that capillaries were 20.23, 14.34, 11.78, 12.58, and $12.78 \mu \mathrm{m}$ in diameter in ostrich, duck, pigeon, turkey, and starling, respectively. In this study, we found the diameter of the blood vessels as $13,17 \mathrm{~mm}$ in female and 13,18 in male, in small numbers, the diameter of capillary vessels as $2.38 \mathrm{~mm}$ in female and $2.40 \mathrm{~mm}$ in male and more in number. In addition, pigmented 
cells were observed around the capillaries. In addition, PAS and GS staining methods which were not included in previous studies were applied in this study. In the PAS staining method, PAS positive reaction was observed around blood vessels, capillaries and pigment cells. However, reticular fibers were not found in the Gordon Sweet stain. We did not find any study on the histological, histochemical and histometric properties of pecten oculi in different genders in the literature. As a result,there was no difference between male and female pecten oculi in our study.

\section{RECOMMENDATIONS}

In various living species, pecten oculi differ morphologically, histometrically and histologically. This is related to the way the creature lives. In this study, pecten oculi of the same species were compared between genders. Histometrically, although we did not have statistical significance, we obtained different values from each other. However, we believe that an increase in sample size and the inclusion of different age groups into the work will contribute to clarifying this issue.

\section{ACKNOWLEDGEMENT}

We would like to thank our staff of Selcuk University Veterinary Faculty Histology and Embryology Laboratory. A part of this work was presented orally at the International Conference on Problems and Solutions in Human and Nature Sciences (IHANAS).

\section{REFERENCES}

Brach V, 1977. The Functional Significance Of The Avian Pecten: A Review. The Condor, 79, 321-327.

Braekevelt CR, 1984. Electron microscopic observations on the pecten of the nighthawk (Chordeiles minor). Ophthalmologica, 189, 211-20.

Braekevelt CR, 1988. Fine structure of the pecten of the pigeon (Columba livia). Ophthalmologica, 196 (3), 151-159.

Braekevelt CR, 1990. Fine structure of the pecten oculi of the mallard (Anas platyrhynchos). Canadian Journal of Zoology, 68, 427-432.

Braekevelt CR, 1991. Electron microscopic observations on the pecten of the great blue heron (Ardea herodias). Histology and Histopathology, 6, 345-51.

Braekevelt CR, 1993. Fine structure of the pecten oculi in the great horned owl (Bubo virginianus). Histology and Histopathology, 81, 9-15.

Braekevelt CR, 1994. Fine structure of the pecten oculi in the American crow (Corvus brachyrhynchos). Anathomy Histology Embryology, 23, 357-66.

Braekevelt CR, Richardson KC, 1996. Fine structure of the pecten oculi in the Australian galah (Eolophus roseicapillus) (Aves). Histology and Histopathology, 11 (3), 565-571. 
Braekevelt CR, 1998. Fine structure of the pecten oculi of the emu(Dromaius novaehollandiae). Tissue Cell 30, 157-165.

Cook HC, 1990. "Carbonhydrates" in The Theory and Practice of Histological Techniques. Bancroft JD and Stewens A (eds): The Bath Press, Stratford-upon-Avon. 3rd Ed, UK, pp;143153.

Culling CFA, Allison RT, Barr WT, 1985. Cellular Pathology Technique. 4th Ed, Butterworths, London, pp; 169.

Dayan MO, Ozaydın T, 2013. A Comparative Morphometrical Study of the Pecten Oculi in Different Avian Species. The ScientificWorld Journal, 10, 11-55.

Gerhardt H, Liebner S, Wolburg H, 1996. The pecten oculi of the chicken as a new in vivo model of the blood-brain barrier. Cell and Tissue Research, 285 (1), 91-100.

Gultiken ME, Yildiz D, Onuk B, Karayigit MO, 2012. The morphology of the pecten oculi in the common buzzard (Buteo buteo). Veterinary Ophtalmology, 2, 72-76.

Hossler FE, Olson KR, 1984. Microvasculature of the avian eye: studies on the eye of the duckling with microcorrosion casting, scanning electron microscopy, and stereology. Am J Anat 170:205-221.

Kiama SG, Bhattacharjee J, Maina JN, Weyrauch KD, 1994. A scanning electron microscope study of the pecten oculi of the black kite (Milvus migrans): possible involvement of melanosomes in protecting the pecten against damage by ultraviolet light. Journal of Anatomy, 185 (3), 637-642.

Kiama SG, Maina JN, Bhattacharjee J, Weyrauch KD, 2001. Functional morphology of the pecten oculi in the nocturnal spotted eagle owl (Bubo bubo africanus), and the diurnal black kite (Milvus migrans) and domestic fowl (Gallus gallus var. domesticus): a comparative study. Journal of Zoology, 254 (4), 521-528.

Kiama SG, Maina JN, Bhattacharjee J, Mwangi DK, Macharia RG, K Weyrauch D, 2006. The morphology of the pecten oculi of the ostrich, Struthio camelus. Annals of Anatomy, 188 (6), 519-528.

Lillie RD,1965. In Histopathologic Technic and Practical Histochemistry. 3rd Ed, Blakiston, NewYork.

Meyer DB, 1977. The avian eye and its adaptions. Crescentelli F(eds): In Handbook of Sensory Physiology, The Visual System of Vertebrates, 5, Springer, Berlin, Germany, pp; 549-612.

Micali A, Pisani A, Ventrici C, Puzzolo D, Roszkowska AM, Spinella R, Aragona P, 2012. Morphological and Morphometric Study of the Pecten Oculi in the Budgerigar (Melopsittacus undulatus). The Anatomical Record, 295, 540-550.

Michaelson IC, 1954. Retinal circulation in man and animals. Springfield: CC Thomas. 
Onuk B, Tutuncu S, Alan A, Kabak M, Ince NG, 2013. Macroanatomic, light and scanning electron microscopic studies of the pecten oculi in the stork (Ciconia ciconia). Microscobic Resarch Techniques, 76, 963-7.

Orhan IO, Ekim O, Bayraktaroglu AG, 2011. Morphological investigation of the pecten oculi in quail (Coturnix coturnix japonica). Ankara Univ Vet Fac Journal, 58, 5-1.

Pettigrew JD, Wallman J, Wildsoet CF, 1990. Saccadic oscillations facilitate ocular perfusion from the avian pecten. Nature 343, 362- 363.

Puzzolo D, Micali A, Pisani A, Arco A, Cutroneo G, 1985. Scanning electron microscopic study on the relationship between the peçten oculi and the vitreous capsule in the eye of the adult chicken. Quad Anat Prat 61, 93-98.

Puzzolo D, 1994. Morphological adaptation of the vertebrate eye to the environment. It J Anat Embryol 99, 17-100.

Rahman ML, Lee E, Aoyama M, Sugita S, 2010. Light and electronmicroscopy study of the pecten oculi of the jungle crow (Corvus macrorhynchos). Okajimas Folia Anatomica Japonica, 87 (3), 75-83.

Rochon-Duvigneaud A, 1943. Les yeux et la vision des Vertebres. Paris: Masson et Cie.

Rodieck RW, 1973. The vertebrate retina. Principles of structure and function. W.H. Freeman, San Francisco.

Smith BJ, Smith SA, Braekevelt CR, 1996. Fine structure of the pecten oculi of the barred owl (Strix varia). Histology and Histopathology, 11 (1), 89-96.

Tucker R, 1975. The surface of the pecten oculi in the pigeon. Cell Tissue Res 157, 457-465.

Walls GL, 1942. The vertebrate eye and its adaptive radiation. Cranbrook Press, Bloomfield Hills.

Wolburg H, Liebner S, Reichenbach A, Gerhardt H, 1999. The pecten oculi of the chicken: A model system for vascular differentiation and barrier maturation. International Review of Cytology, 187, 111-159. 
International Journal of Agriculture, Environment and Bioresearch

Vol. 4, No. 04; 2019

ISSN: $2456-8643$

Table 1:The morphometric parameters of pecten oculi in Partridge (Alectoris chukar).

\begin{tabular}{|c|c|c|c|}
\hline $\begin{array}{l}\text { Animal } \\
\text { (Alectoris chukar) }\end{array}$ & $\begin{array}{l}\text { The numbers of } \\
\text { pleats }\end{array}$ & $\begin{array}{l}\begin{array}{l}\text { Diameter } \\
\text { capillaries }\end{array} \\
(\boldsymbol{X} \pm \text { Sd })\end{array}$ & $\begin{array}{l}\text { Thickness } r \\
\text { capillary basement } \\
\text { membrane }(\mu \mathrm{m}) \\
(\mathrm{X} \pm \text { Sd })\end{array}$ \\
\hline Male & $13-14$ & $13,18 \pm 1,12$ & $2,40 \pm 0,76$ \\
\hline Female & 13-14 & $13,17 \pm 1,11$ & $2,38 \pm 0,75$ \\
\hline
\end{tabular}

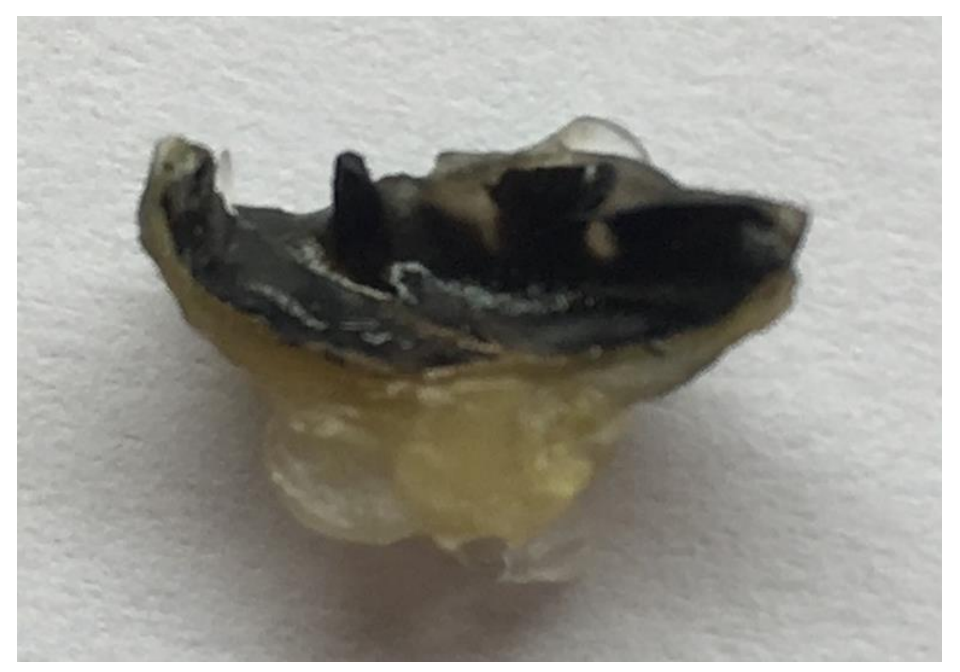

Figure 1:Pectenoculi (arrow) in the Partridge (Alectorischukar).

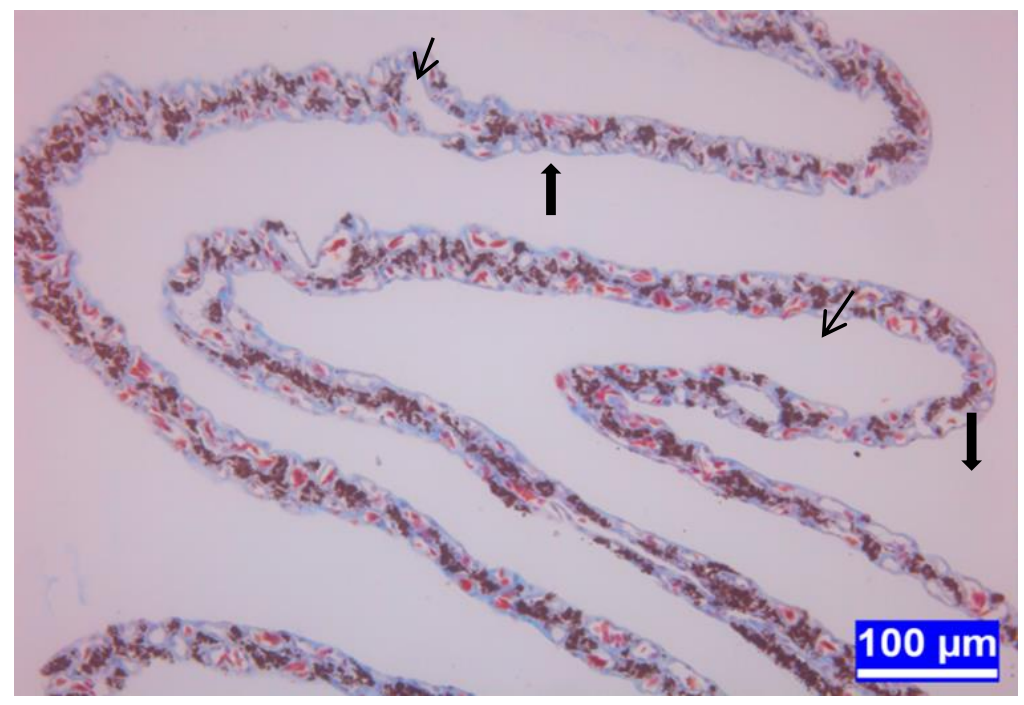


Figure 2: A section from the Alectorischukarpectenoculi; thick arrows: blood vessels, thin arrows: blood capillaries. Mallorytriplestain.

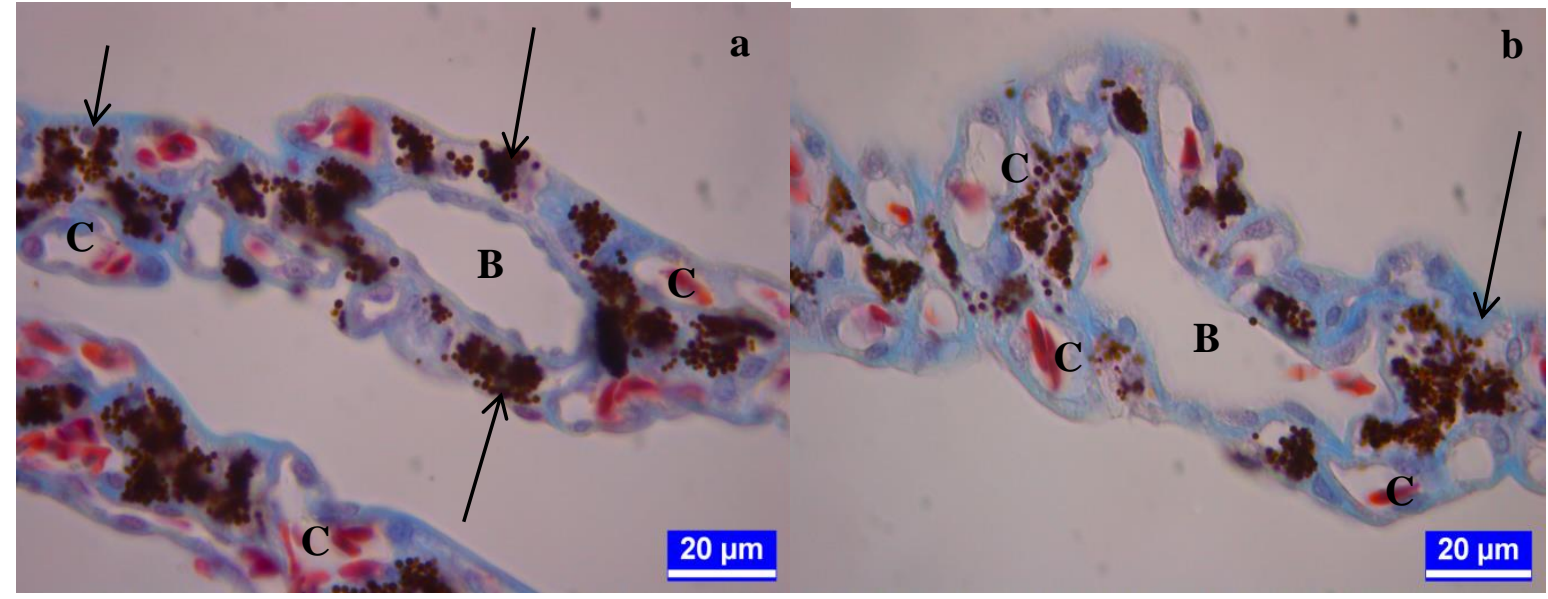

Figure 3: The pigmentation in the pigment cells is noteworthy. Arrows: pigmentation; C: capillaries, B: blood vessel. a: female, b: male. Mallorytriplestain.

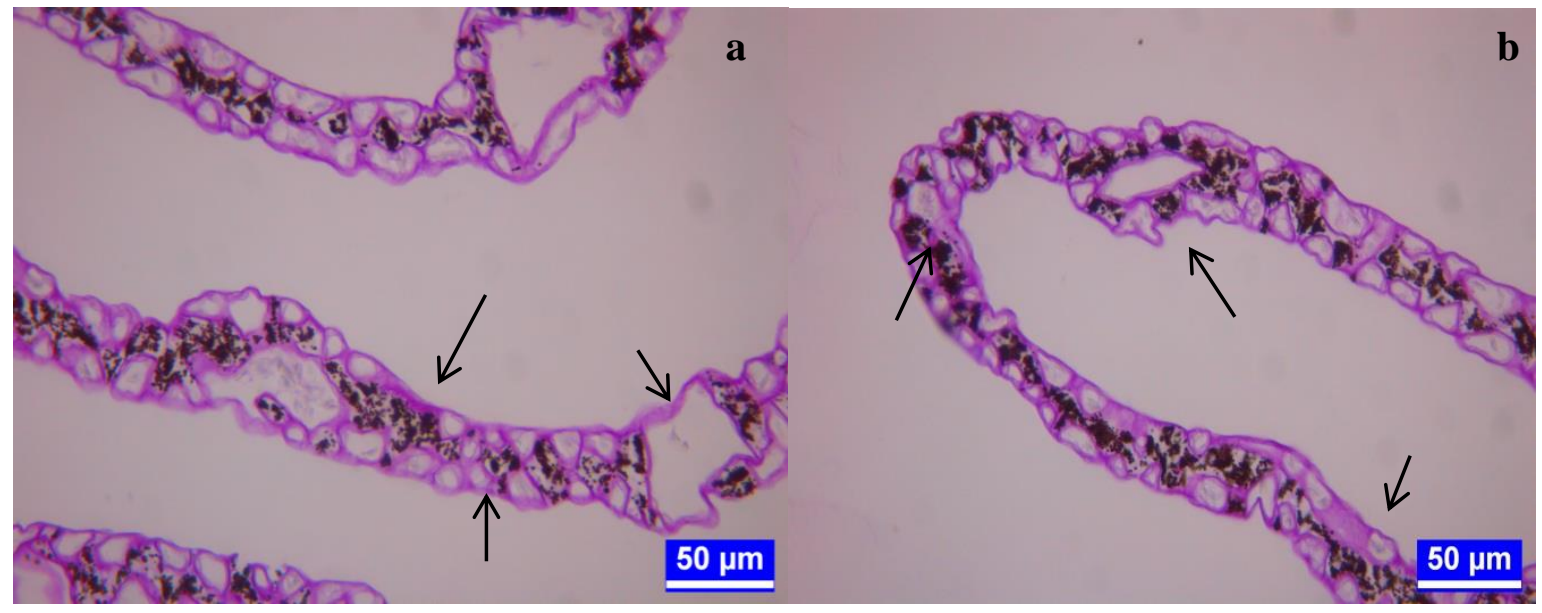

Figure 4: PAS positive reaction around blood vessels, capillaries and pigment cells. Arrows: PAS positive reaction. a: female, b: male. PAS. 